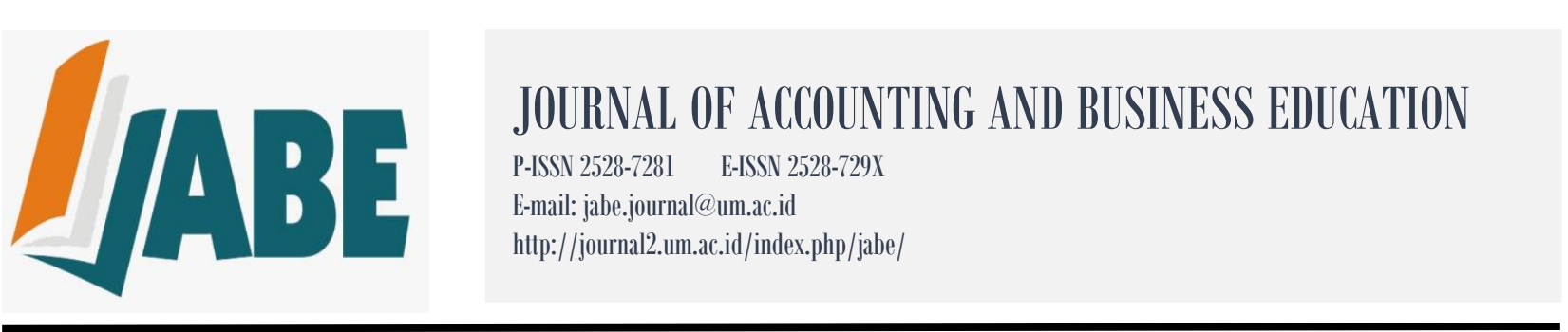

\title{
The Determinant Factors of Performance of Provincial Governments in Indonesia
}

\author{
Hadi Jauhari ${ }^{1}$ \\ Evada Dewata ${ }^{2}$ \\ ${ }^{1}$ Management Department, Faculty of Economic, Politeknik Negeri Sriwijaya, Indonesia \\ ${ }^{2}$ Accounting Department, Faculty of Economic, Politeknik Negeri Sriwijaya, Indonesia \\ email:ha.di@polsri.ac.id
}

DOI: http://dx.doi.org/10.26675/jabe.v3i2.5591

\begin{abstract}
The focus of this research study includes the influence of local government actions, leverage, weaknesses in the internal control system, and audit findings (the Audit Board of the Republic of Indonesia) both partially and simultaneously on the performance of provincial governments in Indonesia for 2015-2016 period. Partially, the size of local government has a positive and significant influence on the performance of local governments. Leverage, weaknesses in the internal control system and findings of the Audit Board of the Republic of Indonesia do not have a significant effect on the performance of local governments. Simultaneously, the size of local government, leverage, weaknesses of the internal control system, and findings of the Board of Audit of the Republic of Indonesia have a significant influence on the performance of local governments with a contribution of the R square effect of $21.29 \%$.
\end{abstract}

Keywords: Local Government Size, Weaknesses of Internal Control Systems, Performance of Local Governments

\section{INTRODUCTION}

The performance of regional government administration related to the accountability of state financial management must be taken seriously. Rather than paying attention merely to input and outcomeissues, the performance and process of organizing the country should be taken into consideration more intensively (Saktiawati, 2014). The implementation of the Government Agency Performance Accountability System in accordance with the Presidential Regulation Number 29 of 2014 concerning the Performance Accountability System of Government Agencies aims at encouraging the performance accountability of government agencies as one of the requirements for the good and reliable governance. However, practically speaking, so far the performance of government administration is still low, as stated by the Secretary General of the Home Ministry Hadi Prabowobased on the three crucial problems occuring in regional governments in need of serious follow-up, including the low level of integrity of both regional government heads and employees, inadequate quality and financial management planning, and long and expensive licensing processes(http://news.metrotvnews.com/).

Under Government Regulation (PP) No. 6 of 2008 concerning Guidelines for Evaluating the Regional Government Administration, it is stated that one of the evaluations of how regional governmentsare administered takes the form of Evaluation of Implementation of Regional Government 
Operations. In 2016, it was noted that from 34 provinces in Indonesia, only 9 had Very Highperformance scores, with the remaining 24 provinces having "High"scores. How could this happen? This is an interesting topic to discuss. One of the perspectives to view this issue is the characteristics of local governments, such as the size of the local government, because the contents of the Regional Government Implementation Reportare highly dependent on the affairs they are in charge of and the characteristics of each local government (Mustikarini and Fitriasari,2012). Quite a number of studies on this topic have revealed different results such as Sumarjo (2010), Kusumawardani (2012), Sari (2016), Artha, Basuki and Alamsyah (2016) where they found that the size of regional government had a positive effect on the performance of regency/municipality governments in Indonesia. The greater the size of the regional government, the greater the resources they own to provide services to the community,thus it is expected that it will improve the performance of the regional governments. On the other hand, Sudarsana (2013) and Dewata, Ilmiyyah\& Sarikadarwati (2017) stated that the size of the regional government did not affect the performance of regional governments.

The performance of regional government administration is also influenced by the level of debt/leverage. Local governments need sources of funds to finance and implement regional development work programs. One source of funds can be in the form of loan/debt capital from external parties. Kusumawardani (2012) stated that leverage was the ratio between debt and capital. Leverage is one of the key performance indicators in evaluating the performance of local governments. This is consistent with the results of research conducted by Sumarjo (2010) who found that leverage influenced the performance of regional government. Meanwhile, the results of Kusumawardani (2012), Artha, Basuki, and Alamsyah (2016) and Dewata, Ilmiyyah\& Sarikadarwati's (2017) research show that leverage does not have a significant effect on the performance of regional government administration.

The weaknessesin the internal control system are of considerable interest in terms of its relationship with the performance of local government administration. These weaknesses include the financial reports which are prepared not in accordance with the standards yet, the inaccurate recording, and the less optimal internal supervisory unit. Under PP No. 60 of 2008 concerning Government Internal Control System, it shall consist of five elements, namely the control environment, risk assessment, control activities, information and communication, and internal control monitoring. The significant weakness in internal control systemmight lead to a waste potentially violating the laws and regulations. The findings of non-compliance with statutory regulations consist of findings of state/regional losses or state/regional losses that occur in state/regional-owned companies, groups finding potential state/regional losses or state/regional losses that occur in state/regional-owned companies, groups findings of a lack of state/regional revenues or state/regional-owned companies, administrative findings and criminal indications (Republic of Indonesia Supreme Audit Agency, 2010). A good compliance (with laws) is part of good management, and it will eventually produce a good performance (Vago, 2008).

\section{LITERATURE REVIEW AND HYPOTHESES}

\section{Performance of Local Government Administration}

In Government Regulation Number 6 of 2008, it is stated that the Performance of Regional Government Administration is the achievement of regional government affairs management as measured using its inputs, processes, outputs, results, benefits, and/or impacts. Measuring the performance of local government is a systematic process of collecting and analyzing data on the regional government administration using a performance measurement system. In accordance with Law Number 23 of 2014, regional government management is the administration of government affairs by regional governments and regional legislatures according to the principle of autonomy and co-administration with the principle of autonomy to the greatest possible extent in the system and principles of the Unitary State of the Republic of Indonesia as referred to in the 1945 Constitution of the Republic of Indonesia. 


\section{Size of Regional Government}

The size of a regional government can be seen from the total assets owned by the regional government. Local governments have the authority to manage regional assets to be used for the public interest. Local governments with greater assets will certainly receive greater pressure from the public to improve its performance and are obliged to disclose its financial reports transparently to reduce information asymmetry.

\section{Leverage}

Leverage shows the amount of debt used by external parties compared to the regional government's own capital. If the amount of debt is greater than the equity, this means that the main source of funding for the entity comes from external parties. The debt or leverage ratio is very important for creditors to measure the ability of local governments to pay their debts. The leverage ratio also shows how much the local government is funded/burdened by debt, if the leverage ratio is high it means the local government has poor performance because its largest funding source is not from its own capital, rather it is from external parties.

\section{Weakness of the Internal Control System}

The Government Internal Control System (SPIP) according to Government Regulation number 60 of 2008 is an integral process in actions and activities carried out continuously by the officers and all employees to provide adequate confidence in achieving organizational goals through effective and efficient activities, reliable financial reporting, safeguarding state assets and compliance with laws and regulations. One of the criteria for the BPK in giving opinions is the number of findings on SPIP weaknesses. The findings of SPIP weaknesses are classifiedinto three categories, namely:

1. Weaknesses in accounting and reporting control system, namely weaknesses in control system related to financial accounting and reporting activities.

2. Weaknesses of the control system for the implementation of the revenue and expenditure budget, namely control weaknesses associated with the collection and deposit of state/regional/state-owned companies' revenues and the implementation of programs/activities in the entities being examined.

3. Weaknesses of internal control structure, namely weaknesses associated with the presence/absence of internal control structure or the effectiveness of internal control structure.

These findings influence the number of findings on SPIP weakness cases which have an effect on the level of effectiveness of the SPIP, which in turn is used as the basis for determining the performance of local government operations.

\section{Findings of the Supreme Audit Agency (BPK) Examination}

The audit findings of BPK as a result of an audit of the local government financial statements contain non-compliance with the statutory provisions. Non-compliance with statutory provisions can result in losses to the region, potential regional financial losses, lack of regional revenues, waste of regional finance or inequality, ineffectiveness, and inefficiency. The increasing number of findings of violations committed by the regional government shows the inefficiency and declining performance of local government.

\section{Effect of the Size of Local Government on the Performance of Local Government Operations}

The size of a large local government will provide ease of operational implementation and will be required to have better performance than the regional governments that have a small size. This is stated by the results of the research of Sumarjo (2010) and Budianto (2012) which stated that the greater the size of the local government, the better the financial performance of the local government. Local governments that have large sizes will also have great pressure to disclose financial performance. Local governments tend to disclose good performance reports only in an attempt to increase its performance score. As Sumarjo (2010), Kusumawardani (2012), Sari (2016) revealed, the size of local government influences the financial performance of local governments. 
Hypothesis 1: The size of local government has a significant effect on the performance of local government operations

\section{Effect of Leverage on the Performance of Local Government Operations}

Leverage relates to the use of assets or funds where the use of these assets requires local governments to cover fixed costs or fixed expenses. Research conducted by Weill (2003) revealed that leverage is a proportion that describes the amount of government debt from external parties compared to own capital. This indicates if the amount of debt is greater than the capital itself, the main source of funding for the entity comes from external parties (Perwitasari, 2009). The level of leverage indicates how much the local government is burdened with debt. If this ratio is high, then the local government may have excess debt and a way to reduce debt must be sought (Sesotyaningtyas, 2012). Perwitasari (2010), revealed that local governments that have high leverage have poor performance because the main funding source comes from external parties.

Hypothesis 2: Leverage has a significant effect on the performance of local government operations

\section{Influence of Weaknesses of the Internal Control System on the Performance of Local Government Operations}

The effectiveness of the internal control system is indicated by the number of findings in the Supreme Audit Agency examination report (Yamin and Sutaryo, 2015). Weaknesses of the internal control system can be classified into three categories, namely the findings of weaknesses in accounting and reporting control system, findings of weaknesses in internal control structure and findings of weaknesses in the control system of the implementation of the revenue and expenditure budget. An effective internal control system will affect performance (Sarita, 2012). The findings of weaknesses in the internal control system make local governments more careful in implementing governance. Weakness of internal control system cases generally occur because responsible officers are not careful in planning and carrying out tasks. The implementation of budget evaluations and feedback is expected to be an effective internal control system assessment, so that the more effective the internal control system is, the more performance will be increased (Ramandei, 2009). The weakness of internal control system of the local government has a significant negative effect on the performance of local government administration as revealed by Vago (2008), Saktiawati (2014) who stated that effective internal control system can produce higher performance.

Hypothesis 3: Weaknesses in the internal control system have a significant effect on the performance of local government operations

\section{Influence of the Supreme Audit Agency's Findings on the Local Government Performance}

The findings in the Local Government Financial Report reveal that non-compliance with laws and regulations has a direct and material effect on the presentation of financial statements. The findings illustrate the deviations that occur during the process of implementing the program/activity, the higher the number of meaningful findings in the implementation of the Regional Budget indicates there are resources that are used for other purposes besides the goals/targets that have been set (Qowi and Prabowo, 2017). In other words, the number of BPK audit findings will illustrate how low the performance of local governments is. The greater the number of BPK audit findings, the lower the performance of local governments. A good compliance practice will always support the efficient and effective function of an organization. So that good compliance is part of good management that will produce good performance (vago, 2008). The more BPK audit findings will show the financial management of the local government is considered low, and will ultimately affect the performance of the local government. (mustikarini and debby, 2008; Qowi and Prabowo, 2017). 
Hypothesis 4: BPK audit findings have a significant effect on the performance of local government operations.

Hypothesis 5: Simultaneously,local government measures, leverage, weaknesses in the internal control system and BPK audit findings have a significant effect on the performance of local government operations.

\section{METHODS}

The population of this study was 34 Indonesian provinces for the period 2015-2016. The sampling criteria of the study were purposive sampling with the provisions of the selected provinces having all the complete data including balance sheet to obtain total assets and total debt, and required local government financial reports for 2015-2016 to obtain the number of audit findings (weakness of internal control systemand BPK audit findings) from the 30 selected provinces which were the unit of analysis of this study.

This research is an associative quantitative study using secondary data which consists of the results of the Determination of Ranking and Status of Local Government Implementation Performance from 2015 to 2016. Reports on Examination of Lcal Government Financial Statements for the 2015-2016 Budget Year are obtained from the Information and Communication Center of the Supreme Audit Agency and from the Summary of Examinations in the first and second semesters of 2015-2016 on the website of the Supreme Audit ; http://www.bpk.go.id.

The performance for Local Government Implementation, measurement using scores based on Decree of Ministry of Home Affairs No. 120-251 of 2014 concerning Determination of Ranking and Status of Local Government Implementation Performance in 2012. There are 4 performance statuses, namely very high (score $\geq 3.0$ ), high ( score $\geq 2.0$ ), moderate (score $\geq 1,0$ ), and low (score $\geq 0.0$ ). Size of Local Governmentis measured based on the total assets owned by the local government (Kusumawardani,2012; Dewata, Ilmiyyah \& Sarikadarwati,2017), the leverage is measured based on proportions that describe the amount of debt from external parties compared to own capital. Researchers in this study use debt to equity ratio to measure leverage. The higher the leverage value, the worse the performance. While the lower the leverage, the better the performance.Measurement of weakness of internal control systemis based on the number of cases of internal control weakness related to accounting records and financial reporting, collection and depositing of state/regional revenues and the implementation of activity programs, the presence/absence of internal control system in the entity being examined.The measurement of the Supreme Audit Agency's audit findings is based on the number of findings of violations of the regulatory provisions that result in regional losses in the report on the results of the examination of the financial statements of the local government.

\section{RESULTS}

Descriptive statistics of this research variable are shown in the following table 1:

Table 1. Descriptive Statistics of Research Variables

\begin{tabular}{|l|ll:lll|}
\hline & EKKPD & size & LEV & SPIP & KP \\
Mean & 0.233333 & 29.80100 & 0.051167 & 7.316667 & 48.90000 \\
\hline Median & 0.000000 & 29.73000 & 0.030000 & 6.000000 & 43.00000 \\
\hline Maximum & 1.000000 & 33.72000 & 0.220000 & 22.00000 & 144.0000 \\
Minimum & 0.000000 & 28.08000 & 0.000000 & 1.000000 & 4.000000 \\
\hline Jarque-Bera & 16.32074 & 60.09239 & 36.32162 & 10.48468 & 5.320809 \\
\hline Probability & 0.000286 & 0.000000 & 0.000000 & 0.005288 & 0.069920 \\
\hline Observations & 60 & 60 & 60 & 60 & 60 \\
\hline
\end{tabular}

Source: processed data from Eviews 6 
From table 1 above, it can be seen that the performance of the implementation of local government is at a High and Very High score, there are around $23.33 \%$ or 7 provinces got the Very High predicate, while the remaining provinces, approximately $76.67 \%$ or 23 provinces, have a High predicate. Furthermore, the Supreme Audit Agency's findings found the most findings in North Sumatra Province as many as 144 cases in 2016, while the fewest findings were obtained in Yogyakarta Province amounted to 4 cases in 2016. The highest number of weakness of internal control systemwas owned by Yogyakarta Province as many as 22 cases in 2015 and the lowest, as many as 1 case, is in Bangka Belitung Islands Province. The largest size of local government is owned by Jakarta Province while the smallest is in West Sulawesi Province. The highest debt level is owned by the Province of South Sumatra in 2015. Before testing the hypothesis, a classic assumption was tested and all tests did not show violations of classical assumptions. The next best model determination on panel data is done using Chow test (Fixed Vs Pool effect) and Hausman test (random Vs Fixed).

Table 2. Chow Test Results

\begin{tabular}{|l|l|l|l|}
\hline effect test & Statisticstest f & P Value & Conclusion \\
\hline Cross-section F & 3.522574 & 0.0009 & fixed effect model accepted \\
\hline
\end{tabular}

Based on table 2, it can be concluded that overall the data is more appropriate to use fixed effect model, which means there is no difference in effect between the time in the panel data. Hausman test is then conducted to find out whether the model from panel data follows the fixed effect model or random effect model.

Table 3. Hausman Test Results

\begin{tabular}{|l|l|l|l|}
\hline effect test & Statisticstest f & P Value & Conclusion \\
\hline Cross-section random & 6.660386 & 0.1550 & random effect model accepted \\
\hline
\end{tabular}

Based on Table 3, it can be concluded that the data is more appropriate to use random effect models when compared to the fixed effect model. Table 4 shows the estimation results for the random effect model.

Table 4. Estimated random effect model

\begin{tabular}{|l|l|l|l|l|}
\hline Variable & Coefficient & Std. Error & t-Statistic & Prob. \\
\hline C & -6.300421 & 1.682930 & -3.743720 & 0.0004 \\
\hline Size & 0.222867 & 0.056259 & 3.961466 & 0.0002 \\
\hline Leverage & -1.587365 & 1.020092 & -1.556100 & 0.1254 \\
\hline SPIP & 0.002361 & 0.010309 & 0.229012 & 0.8197 \\
\hline KP & -0.000899 & 0.001448 & -0.620596 & 0.5374 \\
\hline R-squared & 0.266346 & F-statistic & & 4.991813 \\
\hline Adjusted R-squared & 0.212990 & Prob(F-statistic) & 0.001665 \\
\hline
\end{tabular}

Based on the results of table 4, the results obtained are that in the estimation of the random effect model equation, only the local government size variables that have a significant positive effect on the performance of local government operations. While simultaneously, it is known that the p-value for Fstatistics is 0.001665 smaller than the level of significance $<0.05$ then $\mathrm{H}_{0}$ is rejected (Model is Missed certified), meaning simultaneously, the size of the local government, leverage, weaknesses of the internal control system, and the Supreme Audit Agency's findings have a significant effect on the performance of local government operations in Indonesia. The coefficient of determination is indicated by the adjusted $\mathrm{R}$ square value of 0.2129 , which means that the variability of the dependent variable that can be explained by the independent variable is $21.29 \%$ and the remaining $78.71 \%$ is explained by other variables not included in this research model. 


\section{DISCUSSION}

\section{Relationship of stress exposure in class with work enthusiasm and emotional exhaustion}

The data analysis results show that there is negative relationship between stress exposure in class and work enthusiasm $(B=-0.270 ; p<.001$; see table 1$)$, which means that stress the teachers experience in class has teachers' work enthusiasm lowered. In addition, the data analysis also show positive relationship between stress exposure in class and emotional exhaustion $(B=0.112 ; p<0.001)$, which means that stress exposure the teachers experience in class raises their emotional exhaustion. The findings of this research also show that stress in class is frequently caused by students' behavioral and disciplinary problems during class, students' low learning motivation in class and poor relationship between teacher and students. These have teachers discouraged from going to and teaching in such class in comparison to other classes. Besides lowering work enthusiasm, this also raises teachers' emotional exhaustion.

The results of this research support previous findings that stress in class is dominantly caused by poor (interaction) relationship between teacher and students because of students' disciplinary problem and students' motivation during class, which eventually have teacher's work enthusiasm lowered and emotional exhaustion raised (Gastaldi et al., 2014; Kyriacou, 2001; Fernet et al., 2012; Skaalvik \& Skaalvik, 2010; Pyhältö et al., 2011).

Teacher's lowered work enthusiasm and raised emotional exhaustion are the consequence of poor teacher-students relationship and related to transitional period from student to worker as teacher (beginning teacher). These also conform to the finding of previous researches that transitional period beginning teachers experience is frequently related to their high extent of stress (Dicke et al., 2015; Smith \& Ingersoll, 2004).

Therefore, a teacher, particularly beginning teacher, needs to maintain good relationship with students by, for example, understanding students' character in order to communicate and give them disciplinary and motivational guidance and to strengthen their teacher-students relationship. When this occurs, there will be no more students' disciplinary infringements and low learning motivation in class, thus the teacher will be teaching more enthusiastically and eventually have their emotional exhaustion lowered.

\section{Relationship of stress exposure outside class with work enthusiasm and emotional exhaustion}

The data analysis results show negative relationship between stress exposure outside class and work enthusiasm $(B=-0.360 ; p<.001$; see table 1$)$, which means that when a teacher is under stress outside class, his/her work enthusiasm will decline. In addition, the data analysis results also show positive effect of stress exposure outside class on emotional exhaustion $(B=0.136 ; p<0.001$; see table 1$)$. This shows that stress outside class experienced by teacher will raise his/her emotional exhaustion.Stress exposure outside class is frequently caused by poor relationship with colleagues, particularly with seniors. Besides, working atmosphere also contributes to a teacher's stress, that when in a non-conducive environment like no support from colleagues, a teacher will no longer be comfortable with working (come to school) and will even be reluctant (unwilling) to work, which is one indicator of a teacher's declining work enthusiasm.

The same also occurs in regard to emotional exhaustion. When a teacher has poor relationship with any colleague and uncomfortable working climate (atmosphere) (no support from colleagues), he/she will have his/her patience declining (Maslach, Schaufeli, and Leiter 2001), feel despair, depressed, irritable, frustrated and sad (Wright and Cropanzano 1998), which are signs that his/her emotional exhaustion increases.

The research findings reconfirm previous researches that the reason of stress experienced by teachers comes from outside class, commonly related to relationship with colleagues and working climate, which eventually leads to their declining work enthusiasm and increasing emotional exhaustion (Kyriacou, 2001; Pyhältö et al., 2011; Pomaki et al., 2010; Skaalvik \& Skaalvik, 2011; Van Droogenbroeck et al., 2014).Poor relationship with colleagues is also related to the adaptation process as a teacher from a student. This confirms previous finding that transitional period from student to worker 
(beginning teacher) is frequently associated with high extent of stress (Dicke et al., 2015; Smith \& Ingersoll, 2004). Therefore, a beginning teacher should adapt to work environment, particularly in maintaining good relationship with colleagues in order to create a positive work environment, which will raise his/her work enthusiasm and emotional exhaustion.

\section{CONCLUSION}

The results of this research show that stress exposure in class and outside class significantly influences teachers' psychological well-being from the perspective of work enthusiasm and emotional exhaustion. Moreover, stress exposure in class and outside class negatively influences teacher's work enthusiasm but, on the other hand, positively influences emotional exhaustion. The results of this research prove that beginning teachers are in a critical period for having stress since they are in a transitional phase and, therefore, need appropriate policy related to assignment (of duties), support and positive working climate as preventive measures for them to work smoothly and as realization of their psychological wellbeing.This research is conducted quantitatively and has not revealed in detail the stress the beginning teachers experience, both in and outside class. This allows different stressors between one school and another. Therefore, the researcher suggests future researchers to reexamine the results of this research using different method (qualitative) in order to reveal in more detail stressors beginning teachers experience.

\section{REFERENCES}

Arens, A. K., \& Morin, A. J. S. (2016). Relations between Teachers' Emotional Exhaustion and Students' Educational Outcomes. Journal of Educational Psychology, 108(6), 800-813. https://doi.org/10.1037/edu0000105

Clunies-Ross, P., Little, E., \& Kienhuis, M. (2008). Self-reported and actual use of proactive and reactive classroom management strategies and their relationship with teacher stress and student behaviour. Educational Psychology, 28(6), 693-710. https://doi.org/10.1080/01443410802206700

Demerouti, E., Bakker, A. B., Nachreiner, F., \& Schaufeli, W. B. (2001). The job demands-resources model of burnout. Journal of Applied Psychology, 86(3), 499-512. https://doi.org/10.1037/00219010.86.3.499

Dicke, T., Parker, P. D., Holzberger, D., Kunina-Habenicht, O., Kunter, M., \& Leutner, D. (2015). Beginning teachers' efficacy and emotional exhaustion: Latent changes, reciprocity, and the influence of professional knowledge. Contemporary Educational Psychology, 41, 62-72. https://doi.org/10.1016/j.cedpsych.2014.11.003

Duygulu, E., Ciraklar, N. H., Guripek, E., \& Bagiran, D. (2013). The Effect of Role Stress on the Employee's Well-being: A Study in the Pharmaceutical Companies in the City of Izmir. Procedia - Social and Behavioral Sciences, 84, 1361-1368. https://doi.org/10.1016/j.sbspro.2013.06.757

Fernet, C., Guay, F., Senécal, C., \& Austin, S. (2012). Predicting intraindividual changes in teacher burnout: The role of perceived school environment and motivational factors. Teaching and Teacher Education, 28(4), 514-525. https://doi.org/10.1016/j.tate.2011.11.013

Gastaldi, F. G. M., Pasta, T., Longobardi, C., Prino, L. E., \& Quaglia, R. (2014). Measuring the influence of stress and burnout in teacher-child relationship. European Journal of Education and Psychology, 7(1), 17-28.

Ghozali, I. (2014). Model Persamaan Struktural: Konsep dan Aplikasi dengan Program AMOS 22. Semarang: Badan Penerbit Universitas Diponegoro. 
Keller, M. M., Goetz, T., Becker, E. S., Morger, V., \& Hensley, L. (2014). Feeling and showing: A new conceptualization of dispositional teacher enthusiasm and its relation to students' interest. Learning and Instruction, 33, 29-38. https://doi.org/10.1016/j.learninstruc.2014.03.001

Klusmann, U., Kunter, M., Trautwein, U., Lüdtke, O., \& Baumert, J. (2008). Teachers' occupational wellbeing and quality of instruction: The important role of self-regulatory patterns. Journal of Educational Psychology, 100(3), 702-715. https://doi.org/10.1037/0022-0663.100.3.702

Klusmann, U., Richter, D., \& Lüdtke, O. (2016). Teachers' emotional exhaustion is negatively related to students' achievement: Evidence from a large-scale assessment study. Journal of Educational Psychology, 108(8), 1193-1203. https://doi.org/10.1037/edu0000125

Krapp, A. (2002). Structural and dynamic aspects of interest development: theoretical considerations from an ontogenetic perspective. Learning and Instruction, 12(4), 383-409. https://doi.org/10.1016/S0959-4752(01)00011-1

Kunter, M., Klusmann, U., Baumert, J., Richter, D., Voss, T., \& Hachfeld, A. (2013). Professional competence of teachers: Effects on instructional quality and student development. Journal of Educational Psychology, 105(3), 805-820. https://doi.org/10.1037/a0032583

Kunter, M., Tsai, Y.-M., Klusmann, U., Brunner, M., Krauss, S., \& Baumert, J. (2008). Students' and mathematics teachers' perceptions of teacher enthusiasm and instruction. Learning and Instruction, 18, 468-482. https://doi.org/10.1016/j.learninstruc.2008.06.008

Kyriacou, C. (2001). Teacher Stress: Directions for future research. Educational Review, 53(1), 27-35. https://doi.org/10.1080/00131910120033628

Maslach, C., Jackson, S., \& Leiter, M. (1997). The Maslach Burnout Inventory Manual. In Evaluating Stress: A Book of Resources (Vol. 3, pp. 191-218).

Maslach, C., Schaufeli, W. B., \& Leiter, M. P. (2001). Job Burnout. Annual Review of Psychology, 52(1), 397-422. https://doi.org/10.1146/annurev.psych.52.1.397

Pekrun, R. (2006). The Control-Value Theory of Achievement Emotions: Assumptions, Corollaries, and Implications for Educational Research and Practice. Educational Psychology Review, 18(4), 315341. https://doi.org/10.1007/s10648-006-9029-9

Pianta, R. C. (2001). STRS: student-teacher relationship scale: professional manual. Lutz, FL: Psychological Assessment Resources.

Pomaki, G., DeLongis, A., Frey, D., Short, K., \& Woehrle, T. (2010). When the going gets tough: Direct, buffering and indirect effects of social support on turnover intention. Teaching and Teacher Education, 26(6), 1340-1346. https://doi.org/10.1016/j.tate.2010.03.007

Pyhältö, K., Pietarinen, J., \& Salmela-Aro, K. (2011). Teacher-working-environment fit as a framework for burnout experienced by Finnish teachers. Teaching and Teacher Education, 27(7), 11011110. https://doi.org/10.1016/j.tate.2011.05.006

Renninger, K. A. (2000). Individual interest and its implications for understanding intrinsic motivation. In Intrinsic and extrinsic motivation: The search for optimal motivation and performance (pp. 373404). San Diego, CA, US: Academic Press.

Ryan, R., \& Deci, E. (2000). Self-Determination Theory and the Facilitation of Intrinsic Motivation, Social Development, and Well-Being. The American Psychologist, 55, 68-78. https://doi.org/10.1037/0003-066X.55.1.68

Shen, B., McCaughtry, N., Martin, J., Garn, A., Kulik, N., \& Fahlman, M. (2015). The relationship between teacher burnout and student motivation. British Journal of Educational Psychology, 85(4), 519-532. https://doi.org/10.1111/bjep.12089 
Siegrist, J., Starke, D., Chandola, T., Godin, I., Marmot, M., Niedhammer, I., \& Peter, R. (2004). The measurement of effort-reward imbalance at work: European comparisons. Social Science \& Medicine, 58(8), 1483-1499. https://doi.org/10.1016/S0277-9536(03)00351-4

Skaalvik, E. M., \& Skaalvik, S. (2010). Teacher self-efficacy and teacher burnout: A study of relations. Teaching and Teacher Education, 26(4), 1059-1069. https://doi.org/10.1016/j.tate.2009.11.001

Skaalvik, E. M., \& Skaalvik, S. (2011). Teacher job satisfaction and motivation to leave the teaching profession: Relations with school context, feeling of belonging, and emotional exhaustion. Teaching and Teacher Education, 27(6), 1029-1038. https://doi.org/10.1016/j.tate.2011.04.001

Smith, T. M., \& Ingersoll, R. M. (2004). What Are the Effects of Induction and Mentoring on Beginning Teacher Turnover? American Educational Research Journal, 41(3), 681-714. https://doi.org/10.3102/00028312041003681

Van Droogenbroeck, F., Spruyt, B., \& Vanroelen, C. (2014). Burnout among senior teachers: Investigating the role of workload and interpersonal relationships at work. Teaching and Teacher Education, 43, 99-109. https://doi.org/10.1016/j.tate.2014.07.005

Wright, T. A., \& Cropanzano, R. (1998). Emotional exhaustion as a predictor of job performance and voluntary turnover. Journal of Applied Psychology, 83(3), 486-493. https://doi.org/10.1037/00219010.83.3.486 